\begin{tabular}{|l} 
JURNAL \\
Pendidikan Dasar dan Keguruan \\
Volume 1, No. 1, 2019 \\
ISSN (print) : 2527-578X \\
Homepage : \\
\end{tabular}

\title{
MEMBANGUN KECERDASAN SPIRITUAL ANAK
}

\author{
Hasmiati \\ IAI Muhammadiyah Sinjai \\ miaelbugis@gmail.com,
}

\begin{abstract}
Abstrak
Di dalam jiwa manusia terdapat getaran jiwa yang halus yang ditimbulkan karena suatu ibadah batin yang dilakukan yang fokusnya tentang kebesaran Allah swt atau yang cara melakukan Dzikir. Bila hati berdzikir kepada Allah swt. Maka akan memantulkan cahaya ketenangan batin. Hati atau batin bagaikan sebuah tabung resonansi gitar.Setiap kita berbuat sesuatu, baik itu pada taraf berfikir maupun berbuat, selalu terjadi getaran di hati kita.Getaran tersebut bisa halus dan bisa pula kasar, bergantung bagaiman getaran itu muncul.Jika kita bergembira hati kita bergetar namun juga jika kita bersedih hati kita pun bergetar.disinilah fungsinya titik God Spot untuk mengendalikan peran dan fungsi hati. Oleh karena itu, ciri-ciri manusia yang jiwanya tenang jika diperdengarkan ayat-ayat kebesaran allah swt yakni jika dibacakan Asma Allah.
\end{abstract}

Kata Kunci:Spiritual Quotient

\section{Pendahuluan}

Kecerdasan spiritual adalah kecerdasan untuk menghadapi persoalan makna yaitu; kecerdasan untuk menempatkan perilaku hidup dalam konteks makna yang lebih luas dan kaya. Kecerdasan untuk menilai bahwa tindakan atau jalan hidup seseorang lebih bermakna dibandingkan yang lain. Dan menyangkut tentang asas kejiwaan yang dalam perspektif Islam.Dimensi spiritual senantiasa berkaitan langsing dengan realitas Ilahi. Tuhan Yang Maha Esa spiritual terkait dengan nurani, dan maknawi dari segala sesuatu . makna inti dari kata spirit berikut kata jadinya bermuara pada kehakikian, keabadian dan ruh bukan sifatnya sementara atau tiruan. Kecerdasan spiritual (SQ) adalah untuk menjawab kejadian-kejadian dimanerus mencari makna dan pencarian untuk apa itulah pada fungsi otak yang disebut dengan good spot ( titik Tuhan) kecerdasan spiritual bukanlah angan-angan, kecerdasan spiritual bukanlah ilmu dari luar, kecerdasan spiritual adalah makna dalam dimana manusia akan terus mencari makna kehidupannya (Agustian, 2001)

Membangun spiritual adalah usaha membangun refresing atau ruhani berupa keyakinan, iman, ideology, etika, dan pedoman atau tuntutan. Memembangunspiritualisme dapat dilakukan dengan berbagai media. Salah satunya adalah yang membangun spiritulitas religious. Spritulialitas religious adalah merupakan kewajiban bagi uamt beragama untuk mengembangkan, menguatkan atau membangun kembali peran spiritualitas yang bersumber pada ajaran Tuhan, diyakini memiliki kekuatan spiritual yang lebih kuat, murni, suci, terarah dan abadi. Membangun spiritualitas religious dengan demikian, merupakan kebutuhan untuk mewujudkan ditengah kehidupan masyarakat modern. Membangun spiritual adalah usaha penyegaran mental atau ruhani keyakinan,iman, ideology, etika dan pedoman atau tuntunan. Membangun spiritualisme dapat dilakukandengan berbagai media, salah satunya adalah dengan membangun spiritualitas yang bersumber dari agama(religi) yang dinamakan "spiritualisme-religius. (Wahab, 2010: 45). Adalah kewajiban bagi umat beragama untuk mengembangkan, menguatkan atau membangun kembali peran spiritualitas-religius. Spiritualitasreligius yang pada dasarnya merupakan bentuk spiritualitas yang bersumber pada ajaran Tuhan diyakini memiliki kekuatan spiritual yang lebih kuat murni,suci, terarah dan abadi dibandingkan spiritualitas sekuler dengan berbagai coraknya. 
Penelitian ini merupakan penelitian kualitatif dengan menggunakan metode deskriptif melalui kajian-kajian terdahulu serta merujuk pada beberapa referensi terpercaya.

\section{Hasil dan Pembahasan}

\subsection{Pengertian Spiritual Queotient}

Secara konseptual kecerdasan spiritual terdiri atas gabungan kata kecerdasan dan spiritual, maka, sebelum menelaah tentang pengertian Spiritual Quotient ( SQ) atau kecerdasan spiritual secara komprehensif. Menurut Danah Zohar dan Ian Marshall, kecerdasan Spiritual (SQ) adalah kecerdasan untuk menghadapi persoalan makna atau value, yaitu kecerdasan untuk menempatkan perilaku dan hidup kita dalam konteks makna makna yang lebih luas dan kaya, kecerdasan untuk menilai bahwa tindakan atau jalan hidup seseorang lebih bermakna dibandingkan dengan yang lain.

Kecerdasan spiritual melibatkan kemampuan menghidupkan kebenaran yang paling dalam.Itu berarti mewujudkan hal yang baik, utuh, dan paling manusiawi dalam batin. Gagasan, energy, nilai, visi, dorongan dan arah panggilan hidup, mengalir dari dalam, dari suatu keadaan kesadaran yang hidup bersama cinta. Didalam ESQ, kecerdasan spiritual adalah kemampuan untuk memberi makna ibadah terhadap setiap perilaku dengan kegiatan. Melalui langkah-langkah dan pemikiran yang bersifat fitrah, menuju manusia yang seutuhnya, dan memiliki pola pemikiran tauhidi (integritas) serta beprinsip hanya karena Allah swt (Agustian, 2001: 57).

\subsection{Manfaat Kecerdasan Spiritual}

Dukungan ilmu pengetahuan pada eksistensi Spiritual Quotient (SQ) semakin hari semakin kuat dengan justifikasinya. Hal ini dibuktikan dengan ilmy psikologi, sains, teknologi, seni, manajemen, dan kedokteran yang kini tampaknya mengarah kepada fenomena spiritual atau SQ. beberapa manfaat tentang Spiritual Quotioent sebagai berikut :

1. SQ telah menyalakan manusia untuk menjadi manusia seperti adanya sekarang dan memberi potensi untuk "menyala lagi" untuk tumbuh dan berubah, serta menjalani lebih lanjut evolusi potensi manusiawi.

2. Untuk menjadi kreatif, luwes, berwawasan luas, atau spontan secarakreatif.

3. Untuk berhadapan dengan segala eksistensinya, yaitu saat merasa terpuruk, terjebak oleh kebiasaan, kekhawatiran dan masalah masa lalu akibat penyakit dan kesedihan.

4. Pedoman saat berada dalam masalah yang paling menantang dalam hidup beradadiluar yang diharapkan dan dikenal, diluar aturan-aturan yang telah diberikan, melampaui masa lalu, dan melampaui sesuatu yang dilewati.

5. Untuk menjadi lebih cerdas secar spiritual dalam beragama. SQ membawa jantung kesegala sesuatu, kesatuan dibalik perbedaan, ke potensi dibalik ekspresi nyata, SQ mampu menghubungkan dengan makna dan ruh esensial dibelakang semua agama besar. Seseorang yang memiliki SQ tinggi mungkin menjalankan agama tertentu namun tidak secara picik, eksekutif, fanatik atau prasangka.

6. Untuk menyatukan hal-hal yang bersifat intrapersonal dan interpersonal, serta menjembatani kesengajaan antara diri sendiri dan orang lain. Daniel Goleman telah menulis tentng emosi-emosi intrepersonal atau dalam diri, dan emosi-emosi interpersonal, yatu sama-sama digunakan untuk berhubungan dengan orang lain.

7. Untuk mencapai perkembangan diri yang lebih utuh karena setiap orang memiliki potensi itu. Masing-masing membentuk suatu karakter melalui gabungab anatara pengalaman dan visi.

8. Untuk berhadapan dengan masalah baik dan jahat, hidup dan mati, da nasal usul sejati dari penderitaan dan keputusan manusia (Wahab, 2011: 58-59). 
Menurut Al-Qur'an, sebelum bumi dan manusia diciptakan, roh manusia telah mengadakan perjanjian dengan Allah, Allah bertanya kepada jiwa manusia." Bukankah Aku Tuhanmu,?" lalu ruh manusia menjawab, ya, kami bersaksi...." Surah Al-A'raf ayat 172). Namun karena adanya belenggu-belenggu spiritual banyak manusia yang kemudian lali dari fitrah tersebut.

Secara deskripsif dapat kita lihat firman Allah swt sebagai berikut QS : Al-A'raf [7] ayat 172.:

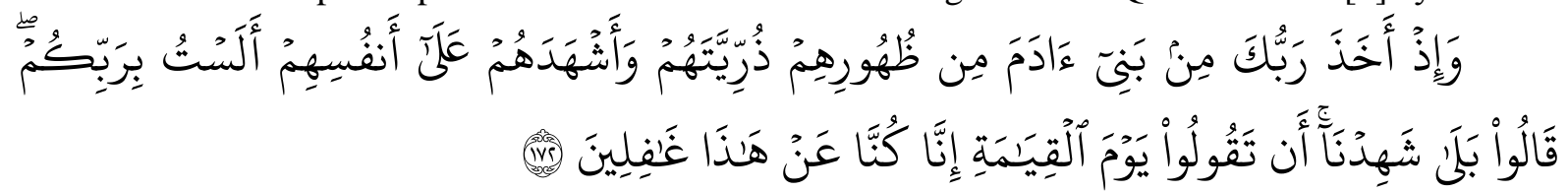

Terjemahan : dan (ingatlah), ketika Tuhanmu mengeluarkan keturunan anak-anak Adam dari sulbi mereka dan Allah mengambil kesaksian terhadap jiwa mereka (seraya berfirman): "Bukankah aku ini Tuhanmu?" mereka menjawab: "Betul (Engkau Tuban kami), Kami menjadi saksi". (kami lakukan yang demikian itu) agar di hari kiamat kamu tidak mengatakan: "Sesungguhnya Kami (Bani Adam) adalah orangorang yang lengah terhadap ini (keesaan Tuhan)" (Departemen Agama RI, 2005: 151).

Bukti nyata adanya perjanjian ini menurut Muhammad Abduh, seperti dikutuip oleh Ary Ginanjar Agustian, ialah adanya fitrah iman di dalam jiwa manusia (Agustian, 2001: 11). Manusia telah dibekati oleh allah swt. dengan fitrah Islam yaitu dengan menaruh iman yang yakin dalam hati mereka. Oleh karena itu, bila manusia hendak berbuat tidak baik pasti akan dilarang oleh suara hati nuraninya. Sebab Tuhan tidak mau manusia berbuat tidak baik. Jika manusia tetap mengerjakan perbuatan tidak baik maka suatu saat pasti ada suara hatinya bernasihat dan ada penyesalan. Mac Scheler mengatakan penyesalan adalah tanda kembali kepada Tuhan. Namun jika suara hati itu tertutup maka mata batinnya itu bisa menjadi buta. Inilah dikatakan tidak cerdas secara spiritual yang disebabkan oleh terbelenggunya kecerdasan hati spiritual. Dengan demikian maka fungsi kecerdasan itu dapat tertutup sehingga tidak kreatif dan hanya mengalami kegagalan dalam suatu usaha. Seperti ini pula dapat menghalangi hati spiritual sehingga titik Tuhan tidak berfungsi dengan baik atau God Spot hal itu merupkan paradigma atau cara pandang seseorang terhadap sesuatu.

Paradigma atau persepsi tercipta karena pengaruh-pengaruh luar yang membentuk paradigma dan pikiran.Sementara dalam God Spot terdapat suara hati yang bersumber dari percikan sifat-sifat Ilahi. God Spot yang berisi bayangan sifat Tuhan itu telah ada dalam diri manusia. Hal itu merupakan kesadaran dasar manusia yang disebut dengan proto kesadaran. Sean Covey dalam buku The 7 Habitats of Hightly Effective Teens menyatakan sebagai berikut:

" Paradigma adalah cara pandang sesuatu, pandanganmu, kerangka acuanmu, atau keyakinanmu. Mungkin sudah kamu perhatikan, bahwa paradigma kita sering kali keliru sehingga menciptakan keterbatasan-keterbatasan. Umpamanya, mungkin kamu yakin bahwa kamu tidak memenuhi syarat untuk kuliah. Tetapi ingatlah, bahwa Ptolemy pun sama yakinnya bahwa bui adalah pusat dari alam semesta (Wahab, 2011: 57-59).

Paradigma seperti kacamata yang harus tepat ukuran lensanya bagi pemakainya. Jika seseorang memiliki paradigma yang tidak lengkap tentang diri sendiri atau kehidupan pada umumnya, itu sama saja mengenakan kacamata yang keliru ukurannya. Lensanya akan mempengaruhi bagaimana dia melihat segalanya.

Pandangan Spiritual tentang kehidupan manusia merupakan sebuah anugerah Allah swt terhadap hambanya.Karena dalam kehidupan manusia dibumi merupakan amanah yang harus dipikul dan tanggungjawab moral yang tinggi. Manusia hidup di dunia melalui proses penghidupan yang panjang mencapai tingkat keberhasilan dan kesuksesan menjadi manusia yang prima. Untuk menjadi manusia prima tersebut terletak pada potensi setiap insan dan bagaiman cara mengelola dan menggunakannya untuk mencapai tujuan mulia tersebut. Potensi ada pada setia manusia dan tergantung manusia itu menerima anugerah dan mau mengubah tanpa selalu pasrahkan diri dan 
menunggu takdir tanpa ada usaha yang sungguh-sungguh sebagai manusia berpikir. Dengan demikian dapat kita lihat pernyataan Allah dalam Al-Qur'an tentang perubahan.

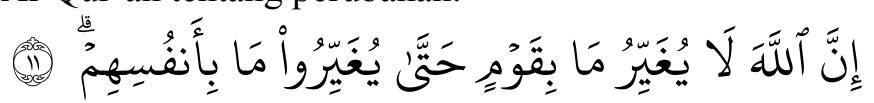

Terjemahan : Sesungguhnya Allah tidak merobah Keadaan sesuatu kaum sehingga mereka merobah keadaan" (QS: Ar-Ra'd ayat 11).

Jadi menurut penulis bahwa nasib diri seorang umat tergantung pada diri mereka sejauh mana kemampuan mengelola potensi yang terdapat dalam dirinya lalu berdo'a kepada Allah ikhlas berbuat karena pengabdian dan ibadah semata karena untuk mencapi hasil usaha harus bekerja lalu yakin akan hasilnya. Selain itu, faktor lain yang mendukung sebuah kesuksesan adalah ilmu pengetahuan dan skill tertentu yang bisa menghasilkan atau bisa berinovasi dan kreatifitas.

Menurut John George "orang yang kreatif mempunyai kekuatan untuk melepaskan diri dari jaringan tekanan-tekanan sosial yang membuat hidup sebagian masyarakat terkatung-katung. Selain itu, ia mampu untuk meragukan setiap pandangan yang kita terima sebagi hal-hal yang bisa diterima" (Asy-Syadzily, 2011: 247).

\subsection{Resonansi Spiritual Quotient}

Resonansi merupakan penularan yang dihasilkan dari sebuah getaran atau pantulan suatu benda yang bergetar. Di dalam jiwa manusia terdapat getaran jiwa yang halus yang ditimbulkan karena suatu ibadah batin yang dilakukan yang fokusnya pada kekuasaan Allah swt atau yang biasa disebut Dzikir.Bila hati berdzikir kepada Allah swt. Maka akan memantulkan cahaya ketenangan batin. Hati atau batin bagaikan sebuah tabung resonansi gitar. Setiap kita berbuat sesuatu, baik itu pada taraf berfikir maupun berbuat, selalu terjadi getaran di hati kita. Getaran tersebut bisa halus dan bisa pula kasar, bergantung bagaiman getaran itu muncul.Jika kita bergembira hati kita bergetar namun juga jika kita bersedih hti kita pun bergetar. Disinilah fungsinya titik God Spot untuk mengendalikan peran dan fungsi hati. Oleh karena itu, ciri-ciri manusia yang jiwanya tenang jika diperdengarkan ayat-ayat kebesaran Allah swt yakni jika dibacakan Asma Allah. Sebagaimana dalam firman Allah dalam QS: Anfal ayat: 2 sebagai berikut.

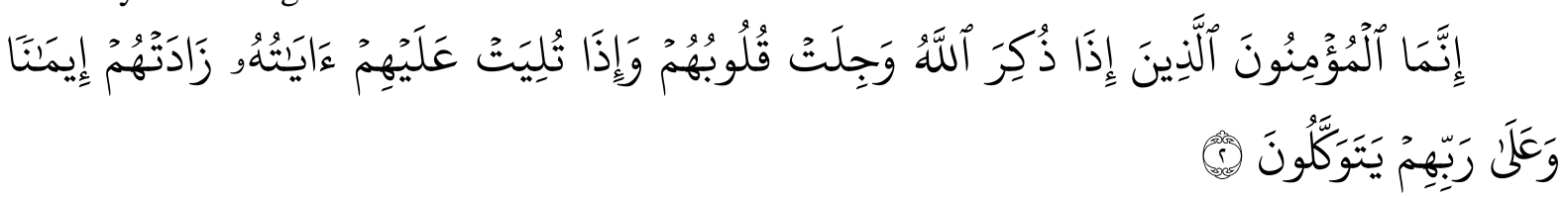

Terjemahan: Sesungguhnya orang-orang yang beriman ialah mereka yang bila disebut nama Allah gemetarlah hati mereka, dan apabila dibacakan ayat-ayat-Nya bertambahlah iman mereka (karenanya), dan hanya kepada Tuhanlah mereka bertawakkal.

Hal ini termasuk salah satu getaran Ilahiah karena hati dapat bergetar karena dibacakan ayat suci al-Qur'an. Ini merupakan getaran tertinggi untuk mencapai suatu ketenangan batin serta terbuka fungsi titik spiritual quostien yang disebakan karena adanya resonansi hati.Berdzikir sabar, ikhlas dan kepasrahan diri dalam beragam (Mustafa, 2008: 151).

Sebagai contoh.Adalah seseorang yang sedang marah.Ketika marah, seseorang akan mengeluarkan getaran kasar hawa nafsu dari hatinya.Jantung hatinya akn bergejolak dan berdetakdetak tidak beraturan.Mukanya merah, telinganya panas dan tangannya gemetaran. Frekuensinya sangat rendah dan kasar dengan amplitudo yang besar. Jika dilihat pada alat pengukur getaran jantung ( ECG- Electric Cardio Graph). Akan terlihat betapa grafik yang dihasilkan sangatlah besar dan bergejolak. Getaran tersebut akan mengahsilkan dampak negatif terhadap tubuh kita. Sebuah benda yang dikenai getarankasar terus menerus akan mengalami kekakuan dan kemudia mengeras. Demikian juga jantung kita orang yang pemarah akan mengalami resiko sakit jantung dan 
mengerasnya pembuluh-pembuluh darahnya. Dan secara psikologis dikatakan hatinya semakin mengeras dan tidak mudah bergetar oleh kebajikan.

Jika seseorang sedang marah, maka seluruh sistem energi dalam tubuh kita akan bergetar dnegan frekuensi yang kemarahan tersebut. Yang mula-mula terserang adalah jantung hati kita. Jantung akan berdetak-detak dengan frekuensi yang kasar. Getaran jantung itulantas akan menjalar ke sel seluruh tubuh kita, dan akhirnya menggetarkanmiliaran bioelektron di dalam tubuh kita. Karena itu,ketika seseorang marah, maka bukan hanyajantungnya yang berdenyut tidak beraturan melainkan juga seluruh tubuhnya gemetaran.

Demikian pula sebaliknya, orang yang sedang dalam kondisi kejiwaan yang stabil.Orang yang sedang senang hatinya maka denyut jantungnya juga sedang tenang, stabil dan lembut.Getaran itu juga mengimbas ke seluruh tubuhnya lewat organ, sel-sel dan otak bioelktron. Karena itu Allah mengatakan di dalam Al-Qur'an.QS. Ar Ra'd (13): 28 :

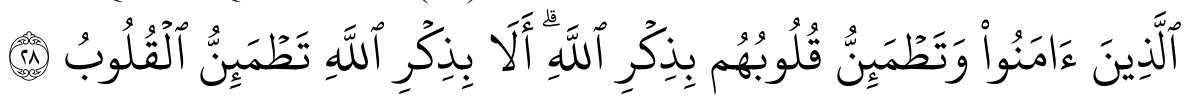

Terjemahan : (yaitu) orang-orang yang beriman dan hati mereka manjadi tenteram dengan mengingat Allah. Ingatlah, hanya dengan mengingati Allah-lah hati menjadi tenteram.

Ayat tersebut memaparkan tentang ciri khas orang memiliki jiwa Spiritual Quotient dapat ditembus oleh cahaya kebenaran dari Tuhan Yang Maha Rahman dan Rahim. Karena mereka itu termasuk orang peduli tentang kerendahan hati mereka sehingga fungsi titik God Spot berfungsi dengan baik. Demikian juga sebaliknya, hati yang keras disebabkan banyak faktor yang mempengaruhi dalam kehidupan sehari-hari sehingga seseorang yang berhati keras itu sangat susah menerima kebenaran yang sumbernya dari Allah swt. Sebab dalam aktivitas selalu dikeliling niat dan perbuatan tidak terpuji atau perbuatan yang jelas dilarang oleh agama. Akhirnya titik Got Spot yang terdapat dalam hatinya tertutup bahkan menjadi buta disebabkan karena mereka sombong, angkuh, riya dan memiliki sifat yang tidak semestinya dimiliki manusia tetapi hanya dimiliki syetan. Oleh karena itu berikut ini beberapa firman Allah yang menyebutkan ciri orang tersebut sebagai berikut:QS: Al-Baqarah $\{2\}$ ayat 7-8:

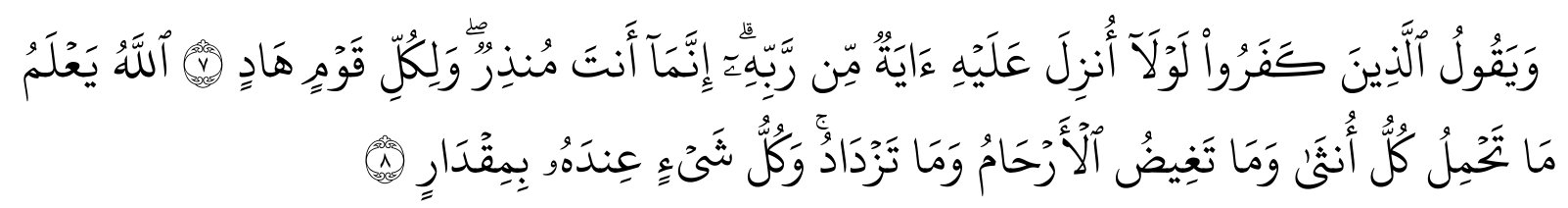

Terjemahan : Allah telah mengunci-mati hati dan pendengaran mereka, dan penglihatan mereka ditutup. dan bagi mereka siksa yang Amat berat. di antara manusia ada yang mengatakan: "Kami beriman kepada Allah dan hari kemudian," pada hal mereka itu Sesungguhnya bukan orang-orang yang beriman.

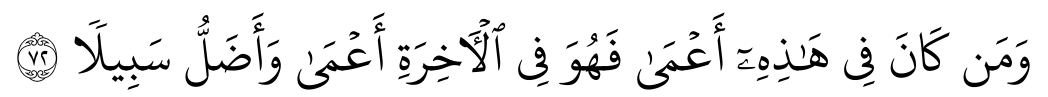

Terjemahan : dan Barangsiapa yang buta (hatinya) di dunia ini, niscaya di akhirat (nanti) ia akan lebih buta (pula) dan lebih tersesat dari jalan (yang benar). QS; AlIsra'(17) ayat ; 72.

\subsection{Spiritualitas Kalbu}

Menurut Imam Al-Gazali bahwa spiritualitas kalbu ia berupa sesuatu yang lathif (halus), bersifat Rabbaniyah ( Ketuhanan) dan kerohanian yang ada hubungannya dengan jasmani. Kalbu yang halus itu manusia dapat menangkap segala rasa, mengetahui dan mengenal segala sesuatu. Kalbu dapat juga diartikan dengan fuad dan Aql. Dalam kamus Besar Bahasa Indonesia disebutkan bahwa 
salah satu pengertian kalbu adalah sesuatu yang ada dalam tubuh manusia yang dianggap sebagai pusat segala perasaan batin dan tempat penyimpanan pengertian-pengertian (perasaan-perasaan dan sebagainya) (Maragustam, 2010: 154).

Kalbu adalah salah satu gejala dari perangkat hakikat manusia yang asasi, karena iman bersemayam di kalbu atau hati. Hal ini dalam Firman Allah QS: Al-Hajj[22]: 32). Berikut:

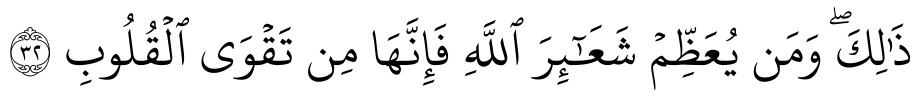

Terjemahan : Demikianlah (perintah Allah). dan Barangsiapa mengagungkan syi'ar-syi'ar Allah, Maka Sesungguhnya itu timbul dari Ketakwaan hati.

Selain itu, kalbu sebagai sarana memperoleh ilmu pengetahuan. Dengan hati kita bisa memperoleh ilmu pengetahuan dan pemahaman yang mendalam yang dibantu oleh penglihatan, dan alat indra yang lain seperti telinga dan lain-lain. Tanpa kalbu maka manusia tidak bisa menjadi apapapa melainkan sama saja perilaku dengan makhluk lain. Justru karena kalbu dapat difungsikan maka mustahil akan menjadi manusia yang paripurna melalui pendidikan yang terstrukur dan berjenjang. Sebab, kalbu itu memerlukan pendidikan dan manajemen yang baik agar terlatih dan terbiasa mengelolah potensi yang dimilikinya. Dengan demikian, adanya kalbu yang lembut tersebut bisa menjadikan manusia menjadi mulia, dermawan, ikhlas, disiplin, berakhlak dan semakin peka terhadap kehidupan sosial di masyarakat.

\subsection{Peran Suara Hati}

Hati berperan untuk dijadikan sebagai pedoman dalam menempuh arus keputasan-keputusan pribadi yang terus-menerus dilakukan dalam kehidupan. Bila perasaan yang kelewat kuat dapat menciptakan kekacauan dalam penalaran, tiadanya kesadaran perasaan dapat pula menjadi bencana, terutama dalam mempertimbangkan keputusan-keputusan yang amat menentukan nasib kita selanjutnya; karier yang kita kejar, apakah bertahan pada pekerjaan yang aman-aman saja atau pindah ke pekerjaan yang beresiko tetapi lebih menarik, siap yang kita ajak menikah, tempat tinggal yang dipilih, rumah yang akan dibeli atau aparteman yang akan disewa, dan itu terjadi terus menerus terjadi selama hidup. Keputusan-keputusan seperti itu tidak dapt dibuat dengan sebaik-baiknya hanya rasionalitas, tetapi membutuhkan suara hati dan kebijaksanaan emosional yang terangkum dari pengalaman-pengalaman masa lampau. Logika formal belakatak pernah dijadikan landasan untuk menentukan siapa yang akan dinikahi atau dipercayai atau bahkan pekerjaan apa yang akan diambil ini adalah wilayah di aman nalar yang tak mengikut sertakan perasaan adalah buta.

Isyarat intuitif yang menuntun kita pada momen-momen semacam itu muncul dalam bentuk dorongan yang digerakkan oleh limbik dari ruang batin oleh Damisio (Goleman, 1995: 73) disebut penenda somatic secara harfiah suara hati.

\section{Simpulan}

Setelah membaca dengan teliti pemaparan di atas dapat disimpulkan bahwa Kecerdasan spiritual melibatkan kemampuan menghidupkan kebenaran yang paling dalam. Itu berarti mewujudkan hal yang baik, utuh, dan paling manusiawi dalam batin. Gagasan, energy, nilai, visi, dorongan dan arah panggilan hidup, mengalir dari dalam, dari suatu keadaan kesadaran yang hidup bersama cinta. Didalam ESQ, kecerdasan spiritual adalah kemampuan untuk memberi makna ibadah terhadap setiap perilaku dengan kegiatan. Melalui langkah-langkah dan pemikiran yang bersifat fitrah, menuju manusia yang seutuhnya, dan memiliki pola pemikiran tauhidi (integritas) serta berprinsip hanya karena Allah swt yang menyangkut tentang asas kejiwaan yang dalam perspektif Islam. Dimensi spiritual senantiasa berkaitan langsung dengan realitas Ilahi. Tuhan Yang Maha Esa spiritual terkait dengan nurani, dan maknawi dari segala sesuatu yang akan membentuk manusia menjadi insan prima. 
Untuk menjadi manusia prima tersebut terlatak pada potensi sertap insan dan bagaiman cara mengelola dan menggunakannya untuk mencapai tujuan mulia tersebut. Potensi ada pada setia manusia dan tergantung manusia itu menerima anugerah dan mau mengubah tanpa selalu pasrahkan diri dan menunggu takdir tanpa ada usaha yang sungguh-sungguh sebagai manusia berpikir.

\section{Daftar Pustaka}

Asy - Syadzily, Karim. Ide Kecil untuk Perubahan Besar. Surakarta: al-Jadid. 2011.

Departemen Agama RI, Al-Qur'an dan Terjemahannya, Cet. X; Bandung: CV Penerbit Diponegoro, 2005.

Ginajar, Ary Agustian. 2001. Rahasia Sukses Membangun Kecerdasan Emosional dan Spiritual. Jakarta : Arga.

Goleman, Daniel. 1995. Emotional Intelligence. Jakarta: PT. Gramedia Pustaka Utama.

Maragustam. 2010. Mencetak Pembelajar Menjadi Insan Paripurna. Yogyakarta: Nuha Litera.

Mustafa,Agus. 2008. Pusaran Energy Ka'bah. Surabaya. PADMA Press.

Wahab H,Abdul.S \& Umiarso. 2011. Kepemimpinan Pendidikan dan Kecerdasan Spiritual. Jakarta: Ar- Ruzz Media. 